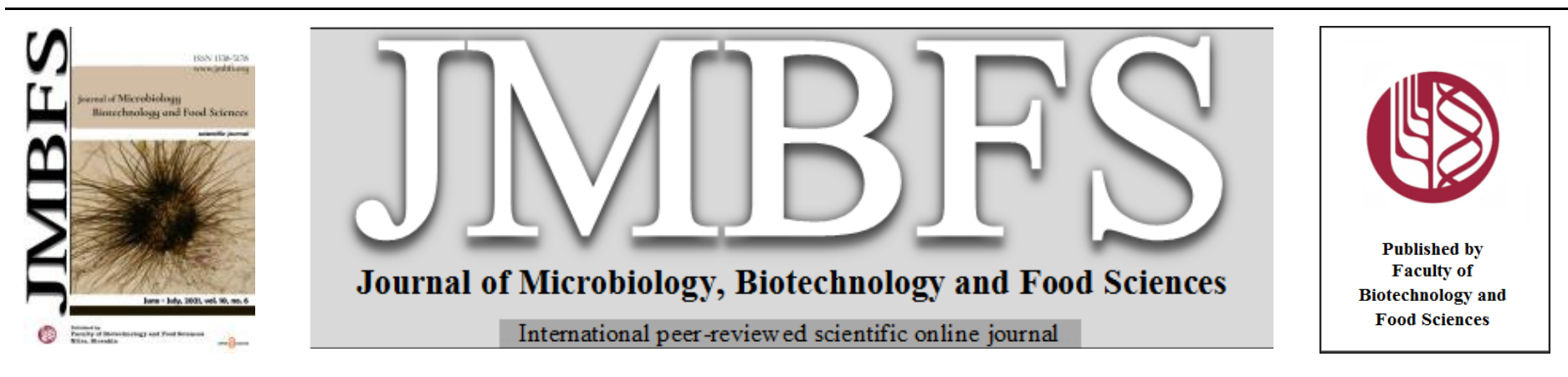

\title{
IN VITRO BIOSYNTHESIS AND ANTIMICROBIAL POTENTIAL OF BIOLOGICALLY REDUCED GRAPHENE OXIDE/AG NANOCOMPOSITE AT ROOM TEMPERATURE
}

\author{
Mohamed M. El-Zahed ${ }^{*}$, Zakaria A. M. Baka ${ }^{1}$, M. I. Abou-Dobara ${ }^{l}$, Ahmed K.A. El-Sayed ${ }^{l}$
}

Address(es): PhD student Mohamed El-Zahed,

${ }^{1}$ Department of Botany and Microbiology, Faculty of Science, Damietta University, New Damietta, Egypt.

*Corresponding author: mohamed.marzouq90@gmail.com or mohamed.marzouq91@du.edu.eg

https://doi.org/10.15414/jmbfs.3956

\section{ARTICLE INFO}

Received 12. 11. 2020

Revised 18. 1. 2021

Accepted 20. 1. 2021

Published 1. 6. 2021

Regular article

open $\mathcal{O}$ access

\begin{abstract}
Antimicrobial resistance is one of the most serious problems that continues to challenge the public health threats and agriculture sectors. The study highlighted one-step method for reduced graphene oxide/Ag nanocomposite (rGO/AgNC) biosynthesis using the supernatant of Escherichia coli D8 (MF062579) strain at room temperature and sunlight. The rGO/AgNC was characterized by UV-vis spectrophotometry, Fourier transform-infrared (FT-IR) spectroscopy and transmission electron microscopy (TEM). Results showed those the rGO-annealed AgNPs showed absorption peak at $430 \mathrm{~nm}$ and have been obtained with an average particle size of $8-17 \pm 9.1$ $\mathrm{nm}$. The MIC value of $\mathrm{rGO} / \mathrm{AgNC}(6.25 \mu \mathrm{g} / \mathrm{mL})$ showed in vitro antimicrobial inhibition against pathogenic bacterial strains such as Gram-negative bacteria (E. coli ATCC25922; 79\%, Klebsiella pneumoniae ATCC33495; 87\%) and Gram-positive bacteria (Staphylococcus aureus ATCC25923; 91\% and Bacillus cereus ATCC6633; 53\%) as well as Candida albicans ATCC10231; 60\% as pathogenic yeast.
\end{abstract}

Keywords: Reduced graphene oxide, silver, nanocomposite, biosynthesis, antimicrobial resistance

\section{INTRODUCTION}

Biofilm forming strain could append to the surface of common antimicrobial agents and start complex establishment (Simoes et al., 2010). This process protects the microbial cells from antibiotics and phagocytosis (Liu et al., 2018). The suppression and derivation of biofilms can be accomplished chemically by disinfectants. All things considered; the proficiency of these chemicals is influenced by various parameters. Thus, new strategies developed to control biofilm development on therapeutic products.

In recent years, antimicrobial potential of metal nanoparticles (NPs) has been improved and may inhibit or kill pathogens, without being toxic to the surrounding tissue (Pop et al., 2020; Rao et al., 2020). In different fields, for example, silver ions used as an antibacterial agent in dental resin composites (Yoshida et al., 1999) and coatings of medicinal tools (Cobos et al., 2020) due to their toxicity to microorganisms (Huerta-Rosas et al. 2020). These days, silver nanoparticles (AgNPs) are used as intense antibiotic agents, comparable in selectivity and efficiency antimicrobial agents than traditional antibiotics (Kouhbanani et al., 2019).

Graphene oxide (GO) might prepare effectively by chemical exfoliation of graphite. It is a monolayers of carbon atoms that may incorporate an enormous number of oxygens containing functional groups for example, carboxyl and hydroxyl groups (William et al., 1958; Wang et al., 2012) that draw scientists because of their owing attributes, for example, low cytotoxicity, chemical and thermal stability, high mechanical strength, good water solubility and large surface area (Jie $\boldsymbol{e t}$ al., 2019). Thus, GO can act as the platform for developing NPs (Yan et al., 2019) to stabilize them (Han et al., 2013) also its antimicrobial potential (Liu et al., 2011; Zou et al., 2016). Consequently, graphene oxide/Ag nanocomposite $(\mathrm{GO} / \mathrm{AgNC})$ assuming it to be a promising potent antimicrobial agent.

The present study provided a one-step green approach for the synthesis of functionalized AgNPs decorated on rGO sheets under different conditions using crude metabolite of Escherichia coli D8 (MF062579) with high antimicrobial activities against the biofilm forming human pathogenic strains such as $E$. coli, Klebsiella pneumoniae, Staphylococcus aureus, Bacillus cereus and Candida albicans due to the synergistic effect of GO and AgNPs.

\section{MATERIAL AND METHODS}

\section{Materials}

The chemicals included graphene oxide (Loba Chemie Pvt. Ltd., India), Silver nitrate (Panreac Quimica S.L.U, Barcelona, Spain) and other chemicals (Sigma Aldrich chemical Pvt. Ltd., India).

The pathogenic strains; E. coli ATCC25922, K. pneumoniae ATCC33495, S. aureus ATCC25923, B. cereus ATCC6633 and C. albicans ATCC10231 in addition to $E$. coli D8 (AC: MF062579); the selected strain for the biosynthesis were obtained from the culture collection of the Laboratory of Microbiology, Botany and Microbiology Department, Faculty of Science, Damietta University, Egypt.

\section{METHODS}

\section{Synthesis of reduced graphene oxide/silver nanocomposite}

E. coli D8 strain was sub-cultured on nutrient agar plates at $37^{\circ} \mathrm{C}$ for $24 \mathrm{hrs}$. and grown on nutrient broth medium at $37^{\circ} \mathrm{C}, 150 \mathrm{rpm}$ for $48 \mathrm{hrs}$. 0.5 McFarland standard $\left(1-2 \times 10^{8} \mathrm{CFU} / \mathrm{ml}\right)$ of $E$. coli $\mathrm{D} 8$ was inoculated into nutrient broth medium at $37^{\circ} \mathrm{C}, 150 \mathrm{rpm}$ for $48 \mathrm{hrs}$. After incubation, the bacterial cultures were centrifuged at $5000 \mathrm{rpm}$ for 20 minutes. The bacterial metabolites were collected for further $\mathrm{rGO} / \mathrm{AgNC}$ synthesis as a bio-reductant.

$0.15 \mathrm{~g}$ of GO powder were dispersed in $50 \mathrm{~mL}$ distilled water and ultrasonicated at $25^{\circ} \mathrm{C}$ (ultrasonic bath, 28kHz Delta-sonic $920 \mathrm{~N}^{\circ} 484$, Meaux, France) for $2 \mathrm{hrs}$. Then, $0.5 \mathrm{~g}$ of $\mathrm{AgNO}_{3}$ was added to the aqueous solution gradually. $20 \mathrm{~mL}$ of bacterial metabolite was added into the reaction mixture in the presence of sun light and at room temperature. The reaction mixture color was turned into dark brown as a first indication for the AgNPs formation and their binding to rGO sheets. The GO/AgNC powder was collected by centrifugation at 10,000 rpm and then dried in an oven at $60^{\circ} \mathrm{C}$ for $24 \mathrm{hrs}$ (Keshvardoostchokami et al., 2018).

Different weights of $\mathrm{AgNO}_{3}(0.5,1,1.5,2,2.5$ and $3 \mathrm{~g})$ and different volumes of bacterial crude metabolite $(10,20,30,40$ and $50 \mathrm{~mL})$ were tested for the best conditions of $\mathrm{rGO} / \mathrm{AgNCs}$ biosynthesis. 


\section{Characterization of the synthesized graphene oxide/silver nanocomposite}

The Ultraviolet-visible (UV-vis) absorption spectra of GO and $\mathrm{rGO} / \mathrm{AgNC}$ were recorded by UV/VIS/NIR Spectrophotometer (V-630, Japan), Faculty of Science, Damietta University. The FT-IR spectral analysis of GO and rGO/AgNC (4000 $400 \mathrm{~cm}^{-1}$ ) were recorded using FT/IR-4100typeA, Faculty of Science, Damietta University. The shape and size of AgNPs, GO and rGO/AgNC were examined by transmission electron microscopy (TEM) on a JEOL JEM-2100, Japan, Electron microscope unit, Mansoura University operated an accelerating voltage of $200 \mathrm{kV}$.

\section{Antimicrobial activity}

The antimicrobial activities of AgNPs and rGO/AgNC were studied against the pathogenic strains by agar well diffusion and broth dilution methods. The bacterial and yeast strains were cultured in nutrient agar and yeast extract peptone dextrose agar (YEPD) plates, respectively and incubated at $37^{\circ} \mathrm{C}$ for $24 \mathrm{hrs}$. Single colonies from bacterial and yeast cultures were inoculated in $20 \mathrm{ml}$ of nutrient broth and YEPD broth, respectively and incubated at $150 \mathrm{rpm}$ at $37^{\circ} \mathrm{C}$ for $24 \mathrm{hrs}$. Then, $200 \mu \mathrm{l}$ of $0.5 \mathrm{McFarland}$ standard $\left(1-2 \times 10^{8} \mathrm{CFU} / \mathrm{ml}\right)$ of microbial suspension was used as a start inoculum for the next tests.

\section{Agar well diffusion method}

The antimicrobial potential of the synthesized $\mathrm{rGO} / \mathrm{AgNC}$ was studied in vitro against pathogenic microbial strains using agar well diffusion method. About $200 \mu$ l of the microbial suspension was inoculated on semi-solidified nutrient agar and YEPD agar plates by pour plate method. Equal volumes $(200 \mu \mathrm{L})$ and same concentrations $(150 \mu \mathrm{g} / \mathrm{ml})$ of the $\mathrm{GO}, \mathrm{rGO} / \mathrm{AgNC}$ and $\mathrm{AgNO}_{3}$ were prepared and added by pipetting the colloidal solution using a sterile micropipette into small wells ( $5 \mathrm{~mm}$ diameter of size) that were made into the solidified agar plates. Penicillin G (antibacterial) and Fluconazole (anticandidal) were used as positive controls. Plates were incubated at $37^{\circ} \mathrm{C}$ (bacteria) and $30^{\circ} \mathrm{C}$ (yeast) for $48 \mathrm{hrs}$. After the incubation period, the plates were examined and zones of inhibition (ZOI) of microbial growth were measured in millimeters for each one (Clinical and Laboratory Standards, 2006).

\section{Broth dilution method}

An autoclaved nutrient broth and YEPD broth media test tubes were prepared and inoculated by $100 \mu \mathrm{l}$ of microbial suspensions $\left(0.5 \mathrm{McFarland}\right.$ standard $\left(1-2 \times 10^{8}\right.$ $\mathrm{CFU} / \mathrm{ml})$ ) in two set of test tubes containing different dosages of $\mathrm{rGO} / \mathrm{AgNC}$ and Penicillin G (antibacterial) or Fluconazole (anticandidal) concentrations (6.25$125 \mu \mathrm{g} / \mathrm{mL}$ ). The inoculated test tubes were incubated at $100 \mathrm{rpm}$ at $37^{\circ} \mathrm{C}$ for 24 hrs. The microbial growth was measured spectrophotometrically at $600 \mathrm{~nm}$ by measuring the optical density (OD) to determine the minimal inhibition concentration (MIC). In similar way, controls were made exclusive of $\mathrm{rGO} / \mathrm{AgNC}$. The growth inhibition percentage was calculated using the following formula:

$\%$ Growth inhibition $=\left[\frac{O D C-O D t}{O D C}\right] \times 100$

Where, ODc and ODt resemble to the OD of the control and tested sample, respectively (Clinical and Laboratory Standards, 2008; 2017).

\section{Transmission electron microscopy study of treated $\boldsymbol{b}$. Cereus}

The ultrastructure of $\mathrm{rGO} / \mathrm{AgNC}$ treated B. cereus (MIC, $6.25 \mu \mathrm{g} / \mathrm{mL}$ ) was studied with TEM (JEOL JEM-2100, Japan, Electron Microscope Unit, Mansoura University, 200kV).

\section{Statistical analysis}

The data were statistically analyzed using software system SPSS version 18. All values in the experiments were expressed as the mean \pm standard deviation (SD).

\section{RESULTS AND DISCUSSION}

\section{Characterization of the synthesized graphene oxide/silver nanocomposite}

The synthesis of $\mathrm{rGO} / \mathrm{AgNC}$ was detected spectrophotometrically as shown in Figure 1. The UV-vis spectrum of GO showed a characteristic peak at $230 \mathrm{~nm}$ which assigned the $\pi-\pi^{*}$ transitions of the aromatic C $-\mathrm{C}$ bonds (de Faria $\boldsymbol{e t}$ al., 2014; Marta et al., 2015). The surface Plasmon resonance peak of AgNPs was appeared at $430 \mathrm{~nm}$ indicating to the annealing of AgNPs in the rGO/AgNC, which matched with the results of Hui et al. (2014) and Chandraker et al. (2017).

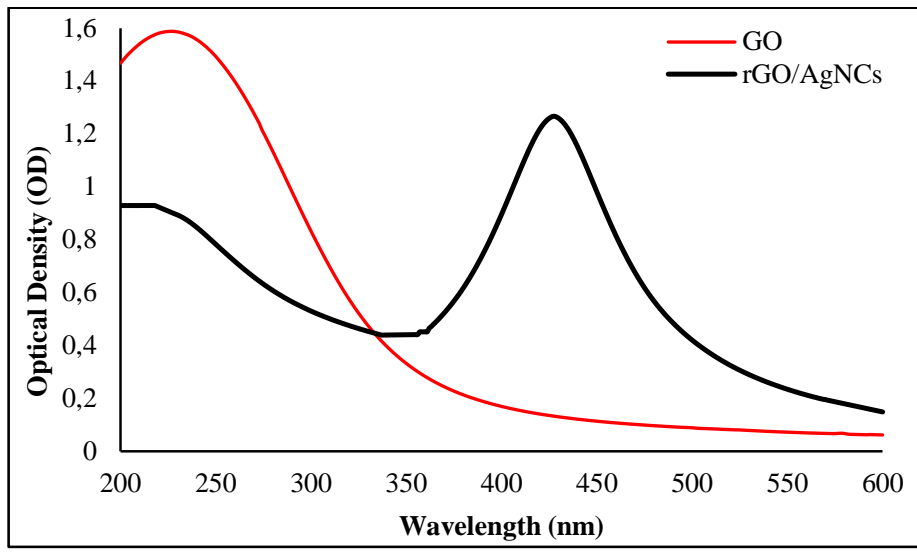

Figure 1 The UV-vis spectra of GO and $\mathrm{rGO} / \mathrm{AgNC}$.

It was found that $1 \mathrm{~g}$ of $\mathrm{AgNO}_{3}$ and $40 \mathrm{~mL}$ of bacterial crude metabolite were the optimal conditions for the biosynthesis of the $\mathrm{rGO} / \mathrm{AgNC}$ that produced the highest amount (absorbance value) and smallest stable AgNPs (blue shifted peak) as shown in Figure $2 \& 3$ (Rai et al., 2009).

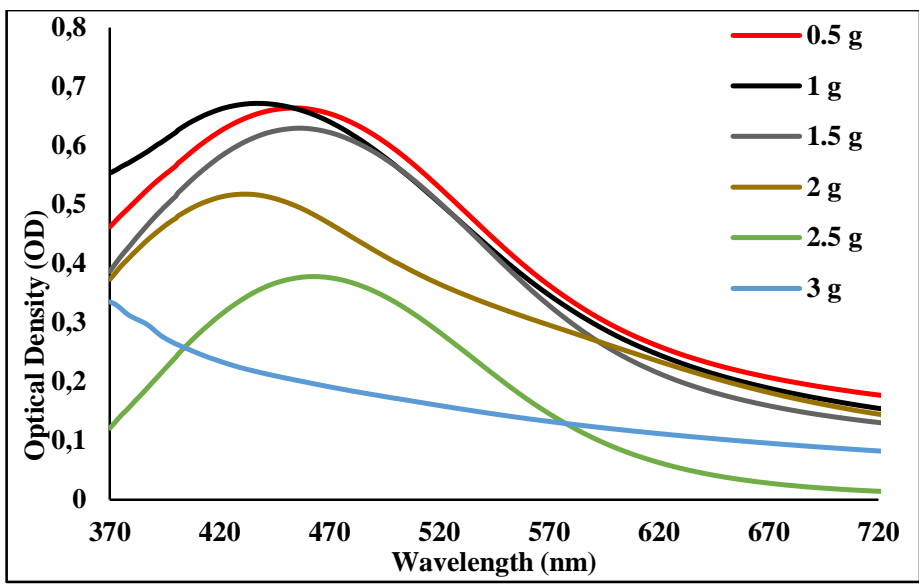

Figure 2 The UV-vis spectra of synthesized the rGO/AgNCs using different weights $(\mathrm{g})$ of $\mathrm{AgNO}_{3}$.

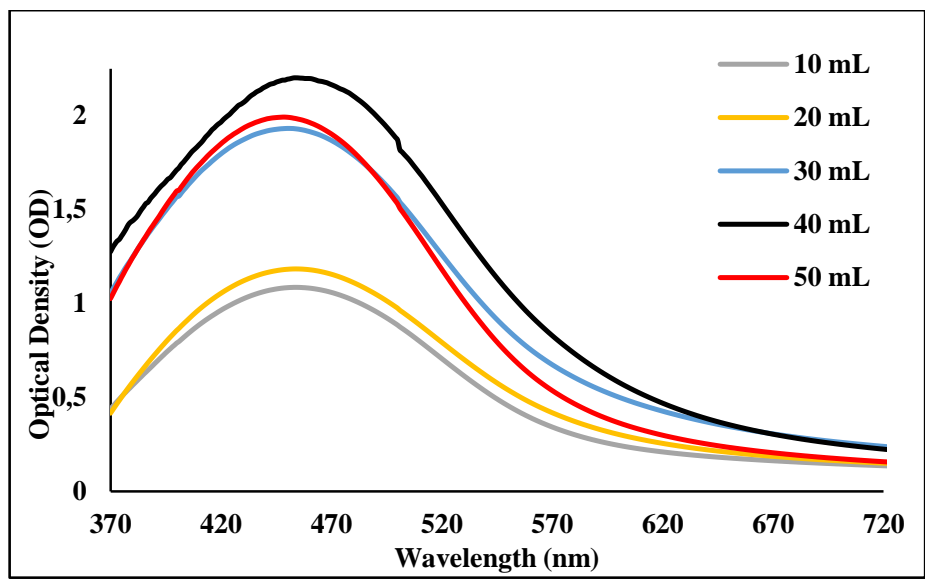

Figure 3 The UV-vis spectra of the synthesized rGO/AgNCs using different volumes $(\mathrm{mL})$ of bacterial crude metabolites.

The binding between GO and AgNPs were confirmed by FTIR spectroscopy. The FTIR spectra of GO and rGO/AgNC were presented in Figure 4. GO displays broad peak at $3440 \mathrm{~cm}^{-1}$, correlated to the hydroxyl groups, and at $1728 \mathrm{~cm}^{-1}$ and $1623 \mathrm{~cm}^{-1}$ reveals an intense peak resembling to the stretching vibrations of carbonyl group (Liu et al., 2020) and aromatic $\mathrm{C}=\mathrm{C}$ bond or intramolecular hydrogen bonds, respectively (Valentini et al., 2013). Other bands at 1240 and $1041 \mathrm{~cm}^{-1}$ related to $\mathrm{C}-\mathrm{O}-\mathrm{H}, \mathrm{C}-\mathrm{H}$ stretching and $\mathrm{C}-\mathrm{O}$ stretching, respectively (Satheesh and Jayavel, 2013). These outcomes approve the presence of exogenous groups and hydroxyl groups on the surface of GO making it suitable for receipting of AgNPs as nano-fillers (Chen et al., 2011). On the other hand, $\mathrm{rGO} / \mathrm{AgNC}$ maintained the peak positions of the functional groups on GO. However, the aromatic $\mathrm{C}=\mathrm{C}$ vibrations $\left(1625 \mathrm{~cm}^{-1}\right)$ of $\mathrm{GO}$ decreased in 
$\mathrm{rGO} / \mathrm{AgNC}$, which denote the successful interaction between functional groups of GO and AgNPs (Shen et al., 2012).

$$
\text { - GO -GO/AgNCS }
$$

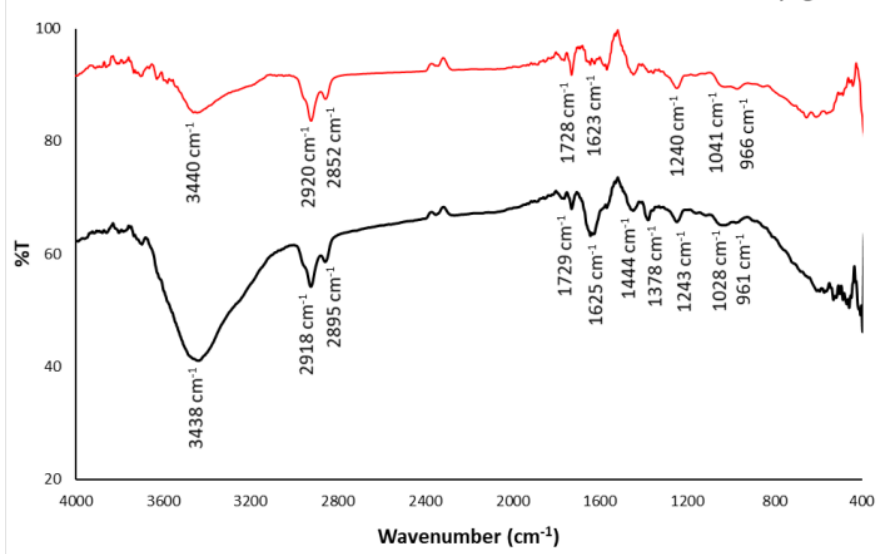

Figure 4 The FTIR spectra of $\mathrm{GO}$ and $\mathrm{rGO} / \mathrm{AgNC}$.

\section{Transmission electron microscopy}

The morphological features of GO and $\mathrm{rGO} / \mathrm{AgNC}$ were studied by TEM. Figure 5 showed a monodisperse layer of spherical-shaped AgNPs (mean size of 8$17 \pm 9.1 \mathrm{~nm}$ ) embedded on the GO sheets which matched with Cobos et al. (2020) and Baka et al. (2019) results. TEM micrograph displayed AgNPs as black dots (spherical and uniformly dispersed on the surface of the transparent and sheetlike structure of GO).

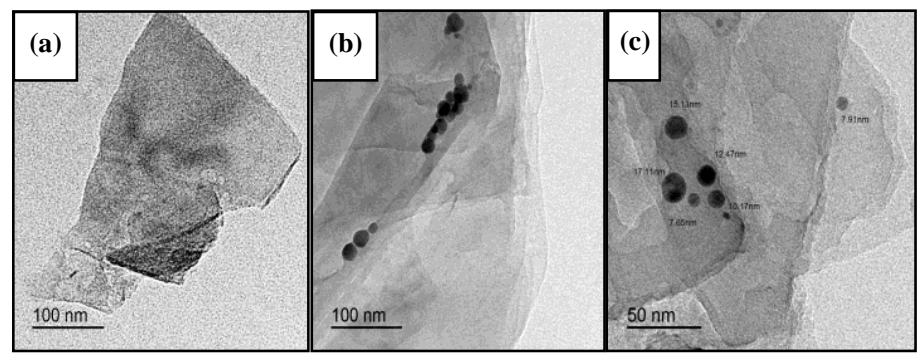

Figure 5 TEM micrograph of GO; (a) and rGO/AgNC; (b; scale bar $=100 \mathrm{~nm}$, c; scale bar $=50 \mathrm{~nm})$.

\section{ANTIMICROBIAL ACTIVITY OF GO AND RGO/AGNC}

Gram-negative (E. coli ATCC25922, K. pneumoniae ATCC33495), Grampositive (S. aureus ATCC25923, B. cereus ATCC6633) bacteria and C. albicans ATCC10231 were selected for the antimicrobial tests because they are usually correlated with the medical-associated infections moreover their antimicrobial resistance. The selected bacterial strains were reported as causing agents for diarrhea or dysentery, and other might cause intestinal infections such as meningitis and urinary tract infections (Simoes et al., 2010). S. aureus could be the cause of gastroenteritis in addition to the secretion of staphylococcal enterotoxins (Kouhbanani et al., 2019). S. aureus and K. pneumoniae were the famous causing pathogens for pneumonia in respiratory diseases (Yoshida et al., 1999). The biosynthesized $\mathrm{rGO} / \mathrm{AgNC}$ showed a potent antimicrobial effect with highly significant different values $(P<0.05)$ between the microbial strains and the diameter of inhibition zone as shown in Figure 6\&7. The antibacterial activities of $\mathrm{rGO} / \mathrm{AgNC}$ might had less effects on B. cereus and E. coli strains than $\mathrm{AgNO}_{3}$ due to their large size that might prevent the penetration of bacterial cell wall. The GO showed better antibacterial potential against the Gram-negative bacteria than the Gram-positive bacteria. Those results might be related to the cell wall contents and peptidoglycan amounts.
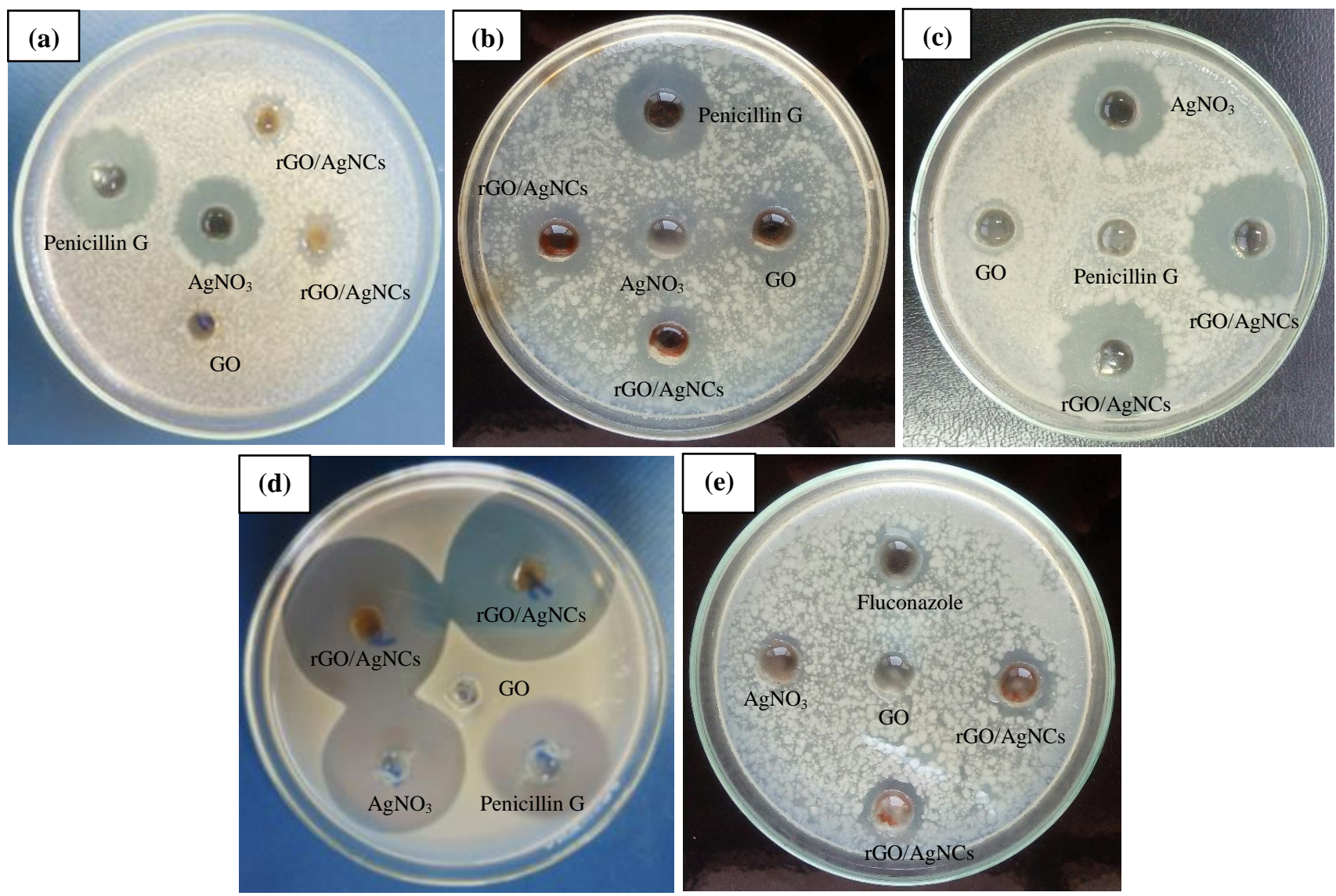

Figure 6 Antimicrobial activity of GO and rGO/AgNCs; (a) B. cereus, (b) E. coli, (c) K. pneumoniae (d) S. aureus and (e) C. albicans. 


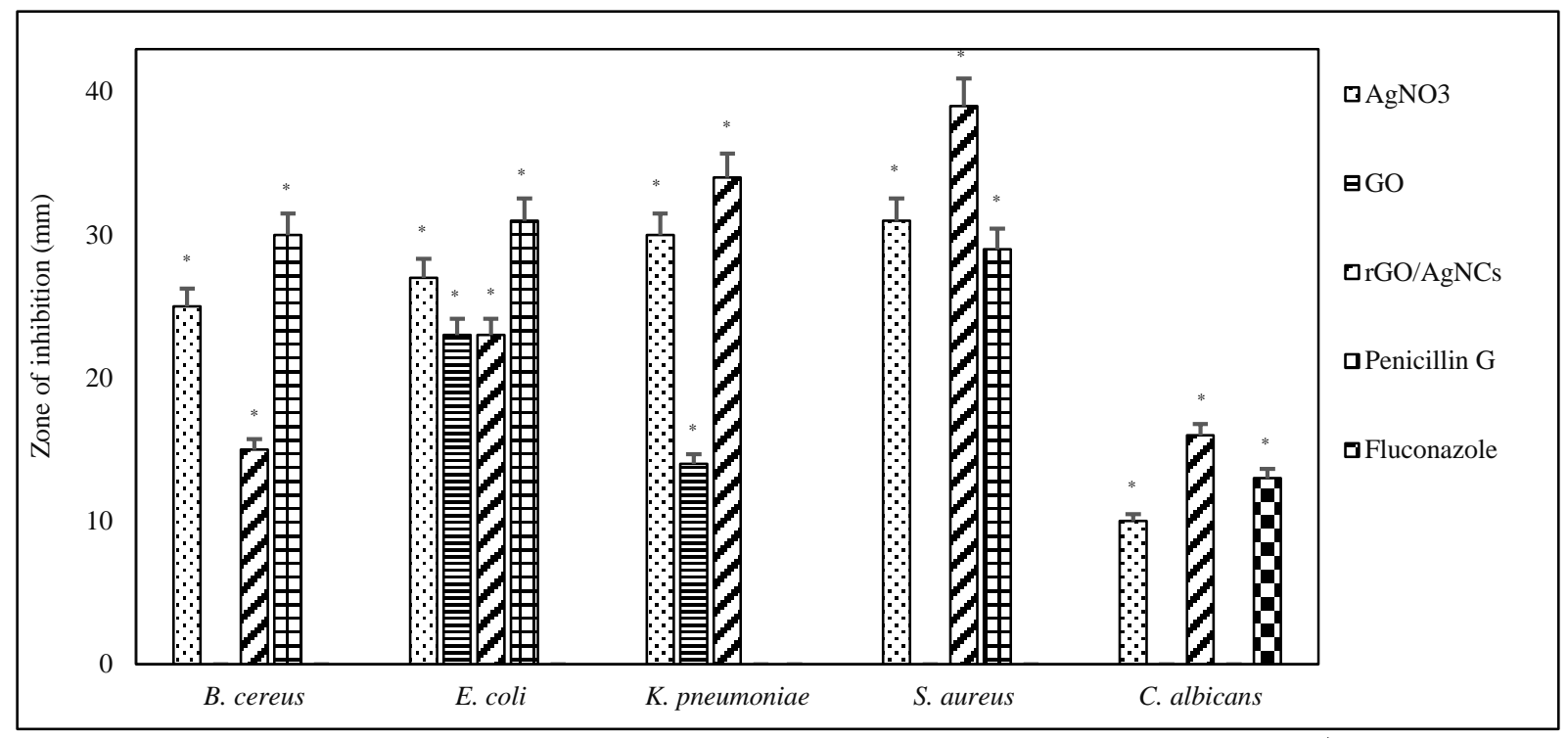

Figure 7 Antimicrobial activity of $\mathrm{AgNO}_{3}, \mathrm{GO}$ and $\mathrm{rGO} / \mathrm{AgNCs}$ against the microbial strains (Highly significant $={ }^{*} P<0.05, n=3$ ).

Antimicrobial ratios for $6.25 \mu \mathrm{g} / \mathrm{mL}$ of $\mathrm{rGO} / \mathrm{AgNC}$ (MIC value) against the microbial strains were E. coli (79\%), K. pneumoniae (87\%), S. aureus (91\%), B. cereus $(53 \%)$ and C. albicans $(60 \%)$ as shown in Figure 8$)$. More than 6.25 $\mu \mathrm{g} / \mathrm{mL}$ dosage antimicrobial ratios attained $100 \%$. Therefore, antimicrobial behavior of $\mathrm{rGO} / \mathrm{AgNC}$ showed a dose-dependent manner. Chandraker $\boldsymbol{e t}$ al. (2017) reported antibacterial ratio for $\mathrm{GO} / \mathrm{AgNC}$ against $E$. coli was reached $91.65 \%$ and against $S$. aureus ratio was $86.75 \%$.

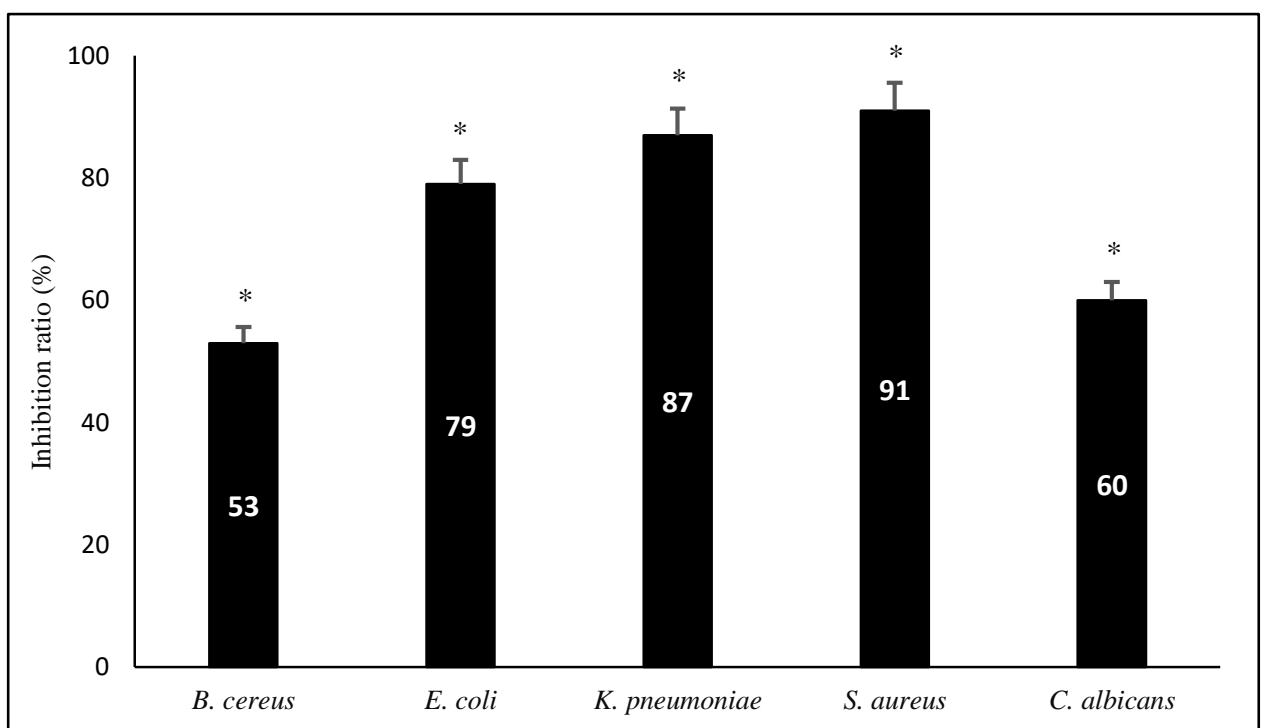

Figure 8 Antimicrobial activity of $\mathrm{rGO} / \mathrm{AgNC}$ (MIC value, $6.25 \mu \mathrm{g} / \mathrm{mL}$ ) against the pathogenic microbial strains (Highly significant $={ }^{*} P<0.05, n=3$ ).

Figure 9 shows the ultrastructure changes of the control and treated B. cereus with synthesized $\mathrm{rGO} / \mathrm{AgNC}$. Untreated $B$. cereus was rod-shaped, with intact cell walls as shown in Figure 9a. After $\mathrm{rGO} / \mathrm{AgNC}$ treating, cell walls of $B$. cereus (Figure $9 \mathrm{~b}$ ) became wrinkled and damaged, led to rupture of bacterial cell membrane. It shows that $\mathrm{rGO} / \mathrm{AgNC}$ revealed good effects on the cell membranes and cell walls of treated bacteria. It has been shown that the synthesized $\mathrm{rGO} / \mathrm{AgNC}$ has bactericidal action by killing the bacteria (Li et al., 2018).

Although the exact mechanism of the antimicrobial action of AgNPs is stil doubtful, there are some reported hypotheses that supposed that AgNPs can interact with phosphorus-containing compounds in cells and sulfur-containing proteins in cell membranes, attacking the respiratory processes and cell division causing cell death (Rai et al., 2009; Sondi and Salopek-Sondi, 2004). Damage might also be caused by the formation of reactive oxygen species (ROS) (Hajipour et al., 2020).

In our study, $\mathrm{rGO} / \mathrm{AgNC}$ were used as an antimicrobial agents, which revealed a superior antimicrobial potential towards biofilm forming strains such as E. coli, K. pneumoniae, S. aureus, B. cereus and C. albicans due to the synergistic effect of GO and AgNPs (Ma et al., 2011; Tomar et al., 2020). These results indicate that the $\mathrm{rGO} / \mathrm{AgNC}$ can be further renovated for upcoming biomedical applications.

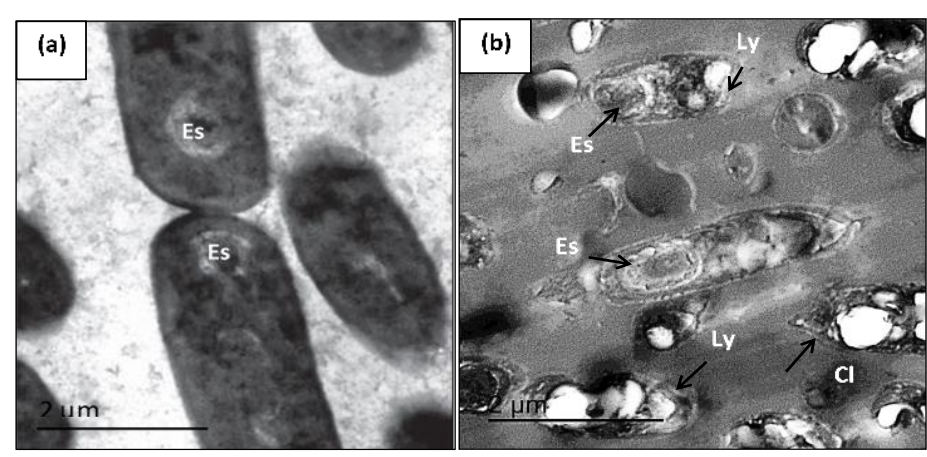

Figure 9 The bactericidal effect of $\mathrm{rGO} / \mathrm{AgNC}$ on the ultrastructure of $B$. cereus (a) A negative control (without $\mathrm{rGO} / \mathrm{AgNC}$ ). (b) A treated sample (at 6.25 $\mu \mathrm{g} / \mathrm{mL}$ ), there are irregular rods (arrows) with lysed cell walls (Ly), malformed cells $(\mathrm{Mc})$ and a complete cell lysis $(\mathrm{Cl})$. Note the endospore formation (Es).

\section{CONCLUSIONS}

A green friendly, simplest hypothesis was outlined to biosynthesize $\mathrm{rGO} / \mathrm{AgNC}$. Spherical shaped AgNPs were well embedded and dispersed on the surface of GO sheets. The synergistic action enhanced the activity compared with simple mixture of $\mathrm{AgNO}_{3}, \mathrm{GO}$, and $\mathrm{rGO} / \mathrm{AgNC}$. Synthesized $\mathrm{rGO} / \mathrm{AgNC}$ revealed 
extremely valuable antimicrobial actions at very low dosages, against Gramnegative and Gram-positive bacteria as well as pathogenic yeast. The results in this study might aid to understand how $\mathrm{rGO} / \mathrm{AgNC}$ interacts with pathogens, and further help the future use of $\mathrm{rGO} / \mathrm{AgNC}$ as a new generation of vigorous antimicrobial material in clinical and industrial applications.

\section{REFERENCES}

Baka ZA, Abou-Dobara MI, El-Sayed AKA, El-Zahed MM. 2019. Synthesis, characterization and antimicrobial activity of chitosan/Ag nanocomposite using $\begin{array}{lllll}\text { Escherichia coli } & \text { D8. } & \text { SJDFS, } & 9: & 1-6\end{array}$ http://publication.du.edu.eg/journal/ojs302design/index.php/sci/article/view/2381 Chandraker K, Nagwanshi R, Jadhav SK, Ghosh KK, Satnami ML. 2017 Antibacterial properties of amino acid functionalized silver nanoparticles decorated on graphene oxide sheets. Spectrochim Acta A Mol Biomol Spectrosc 181: 47-54. https://doi.org/10.1016/j.saa.2017.03.032

Chen J, Zheng X, Wang H, Zheng W. 2011. Graphene oxide-Ag nanocomposite: In situ photochemical synthesis and application as a surface-enhanced Raman scattering substrate. Thin Solid Films 520: 179-185. https://doi.org/10.1016/i.tsf.2011.07.012

Clinical and Laboratory Standards document M100-S26. 2017. Performance standards for antimicrobial susceptibility testing: Approved standard- twentyseven Edition, Clinical and Laboratory Standards Institute, Wayne, Pennsylvania, USA.

Clinical and Laboratory Standards document M2-A9. 2006. Performance standards for antimicrobial disk susceptibility tests: Approved standard- Ninth Edition, Clinical and Laboratory Standards Institute, Wayne, Pennsylvania, USA. Clinical Laboratory Standards document M27-A3. 2008. Reference method for broth dilution antifungal susceptibility testing of yeasts: Approved StandardThird Edition, Clinical and Laboratory Standards Institute, Wayne, Pennsylvania, USA.

Cobos M, De-La-Pinta I, Quindós G, Fernández MJ, Fernández MD. 2020 Synthesis, physical, mechanical and antibacterial properties of nanocomposites based on poly (vinyl alcohol)/graphene oxide-silver nanoparticles. Polymers 12 723. https://doi.org/10.3390/polym12030723

de Faria AF, Martinez DST, Meira SMM, de Moraes ACM, Brandelli A, Souza Filho AG, Alves OL. 2014. Anti-adhesion and antibacterial activity of silver nanoparticles supported on graphene oxide sheets. Colloids Surf B Biointerfaces 113: 115-124. https://doi.org/10.1016/j.colsurfb.2013.08.006

Hajipour P, Bahrami A, Eslami A, Hosseini-Abari A. 2020. Chemical bath synthesis of CuO-GO-Ag nanocomposites with enhanced antibacterial properties. J Alloys Compd 821: 153456. https://doi.org/10.1016/j.jallcom.2019.153456

Han Y, Luo Z, Yuwen L, Tian J, Zhu X, Wang L. 2013. Synthesis of silver nanoparticles on reduced graphene oxide under microwave irradiation with starch as an ideal reductant and stabilizer. Appl Surf Sci 266: 188-193. https://doi.org/10.1016/j.apsusc.2012.11.132

Huerta-Rosas B, Cano-Rodríguez I, Gamiño-Arroyo Z, Gómez-Castro FI, Carrillo-Pedroza FR, Romo-Rodríguez P, Gutiérrez-Corona JF. 2020. Aerobic processes for bioleaching manganese and silver using microorganisms indigenous to mine tailings. World $J$ Microbiol Biotechnol 36: 1-16. https://doi.org/10.1007/s11274-020-02902-6

Hui KS, Hui KN, Dinh DA, Tsang CH, Cho YR, Zhou W, Chun HH. 2014 Green synthesis of dimension-controlled silver nanoparticle-graphene oxide with in situ ultrasonication. Acta Mater 64: 326-332. https://doi.org/10.1016/j.actamat.2013.10.045

Jie Z, Xiao X, Huan Y, Youkang H, Zhiyao Z. 2019. The preparation and characterization of $\mathrm{TiO}_{2} / \mathrm{r}-\mathrm{GO} / \mathrm{Ag}$ nanocomposites and its photocatalytic activity in formaldehyde degradation. Environ Technol 1: 1-13. https://doi.org/10.1080/09593330.2019.1625955

Keshvardoostchokami M, Bigverdi P, Zamani A, Parizanganeh A, Piri F. 2018 Silver@graphene oxide nanocomposite: synthesize and application in removal of imidacloprid from contaminated waters. Environ Sci Pollut Res 25: 6751-6761. https://doi.org/10.1007/s11356-017-1006-y

Kouhbanani MAJ, Beheshtkhoo N, Nasirmoghadas P, Yazdanpanah S, Zomorodianc K, Taghizadeh S, Amani AM. 2019. Green Synthesis of spherical silver nanoparticles using Ducrosia Anethifolia aqueous extract and its $\begin{array}{llll}\text { antibacterial } & \text { activity. } & \text { JETT } & \text { 461-466 }\end{array}$ http://jett.dormaj.com/Volume7 Issue3.html

Li M, Huang L, Wang X, Song Z, Zhao W, Wang Y, Liu J. 2018. Direct generation of $\mathrm{Ag}$ nanoclusters on reduced graphene oxide nanosheets for efficient catalysis, antibacteria and photothermal anticancer applications. J Colloid Interface Sci 529: 444-451. https://doi.org/10.1016/j.jcis.2018.06.028

Liu C, Geng L, Yu Y, Zhang Y, Zhao B, Zhao Q. 2018. Mechanisms of the enhanced antibacterial effect of ${\mathrm{Ag}-\mathrm{TiO}_{2}}_{2}$ coatings. Biofouling 34: 190-199. https://doi.org/10.1080/08927014.2017.1423287

Liu S, Zeng TH, Hofmann M, Burcombe E, Wei J, Jiang R, Chen Y. 2011 Antibacterial activity of graphite, graphite oxide, graphene oxide, and reduced graphene oxide: membrane and oxidative stress. ACS nano 5: 6971-6980. https://doi.org/10.1021/nn202451x
Liu Z, Tian S, Li Q, Wang J, Pu J, Wang G, Ren L. 2020. Integrated dualfunctional ORMOSIL coatings with AgNPs@ rGO nanocomposite for corrosion resistance and antifouling applications. ACS Sustain Chem Eng 8: 6786-6797. https://doi.org/10.1021/acssuschemeng.0c01294

Ma J, Zhang J, Xiong Z, Yong Y, Zhao XS. 2011. Preparation characterization and antibacterial properties of silver-modified graphene oxide. J Mater Chem 21 3350-3352. https://doi.org/10.1039/C0JM02806A

Marta B, Potara M, Iliut M, Jakab E, Radu T, Imre-Lucaci F, Astilean S. 2015 Designing chitosan-silver nanoparticles-graphene oxide nanohybrids with enhanced antibacterial activity against Staphylococcus aureus. Colloids Surf A Physicochem Eng Asp

https://doi.org/10.1016/j.colsurfa.2015.09.046

Pop OL, Mesaros A, Vodnar DC, Suharoschi R, Tăbăran F, Magerușan L, Socaciu C. 2020. Cerium oxide nanoparticles and their efficient antibacterial application In Vitro against Gram-positive and Gram-negative pathogens Nanomaterials 10: 1614. https://doi.org/10.3390/nano10081614

Rai M, Yadav A, Gade A. 2009. Silver nanoparticles as a new generation of $\begin{array}{llll}\text { antimicrobials. } \quad \text { Biotechnol } \quad \text { 27: } & \text { 76-83. }\end{array}$ https://doi.org/10.1016/j.biotechadv.2008.09.002

Rao SS, Saptami K, Venkatesan J, Rekha PD. 2020. Microwave-assisted rapid synthesis of silver nanoparticles using fucoidan: Characterization with assessment of biocompatibility and antimicrobial activity. Int J Biol Macromol 163: 745-755. https://doi.org/10.1016/j.ijbiomac.2020.06.230

Satheesh K, Jayavel R. 2013. Synthesis and electrochemical properties of reduced graphene oxide via chemical reduction using thiourea as a reducing agent. Mater Lett 113: 5-8. https://doi.org/10.1016/j.matlet.2013.09.044

Shen J, Li T, Shi M, Li N, Ye M. 2012. Polyelectrolyte-assisted one-step hydrothermal synthesis of Ag-reduced graphene oxide composite and its antibacterial properties. Mater Sci Eng C 32(7): 2042-2047. https://doi.org/10.1016/j.msec.2012.05.017

Simoes M, Simões LC, Vieira MJ. 2010. A review of current and emergent biofilm control strategies. Lebensm Wiss Technol 43: 573-583. https://doi.org/10.1016/j.1wt.2009.12.008

Sondi I, Salopek-Sondi B. 2004. Silver nanoparticles as antimicrobial agent: a case study on E. coli as a model for Gram-negative bacteria. J Colloid Interface Sci 275: 177-182. https://doi.org/10.1016/j.jcis.2004.02.012

Tomar PC, Kalra T, Kohli H, Arora K. 2020. Augmenting the efficiency of scaffolding in medical therapies with the advent of nanotechnology: Nanotechnology in Medical Therapy. JMBFS 10: 273-278 https://doi.org/10.15414/jmbfs.2020.10.2.273-278

Valentini L, Cardinali M, Fortunati E, Torre L, Kenny JM. 2013. A novel method to prepare conductive nanocrystalline cellulose/graphene oxide composite films Mater Lett 105: 4-7. https://doi.org/10.1016/j.matlet.2013.04.034

Wang X, Huang P, Feng L, He M, Guo S, Shen G, Cui D. 2012. Green controllable synthesis of silver nanomaterials on graphene oxide sheets via $\begin{array}{llll}\text { spontaneous } & \text { reduction. } & R S C & \text { 2: }\end{array}$ https://doi.org/10.1039/C2RA00008C

William S, Hummers JR, Offeman RE. 1958. Preparation of graphitic oxide. $J$ Am Chem Soc 80: 1339-1339. https://doi.org/10.1021/ja01539a017

Yan L, Zhou M, Pang X, Gao K. 2019. One-step in situ synthesis of reduced graphene oxide/Zn-Al layered double hydroxide film for enhanced corrosion protection of magnesium alloys. Langmuir 35: 6312-6320. https://doi.org/10.1021/acs.langmuir.9b00529

Yoshida K, Tanagawa M, Atsuta M. 1999. Characterization and inhibitory effect of antibacterial dental resin composites incorporating silver supported materials. J Biomed Mater Res A 47: 516-522. https://doi.org/10.1002/(SICI)10974636(19991215)47:4\%3C516::AID-JBM7\%3E3.0.CO;2-E

Zou X, Zhang L, Wang Z, Luo Y. 2016. Mechanisms of the antimicrobial activities of graphene materials. $J$ Am Chem Soc 138: 2064-2077. https://doi.org/10.1021/jacs.5b11411 